\title{
ASPECTS OF APPLICATION OF TAX CONTROL BY COUNTRIES FOR CROSS-BORDER OPERATIONS
}

\author{
BORMOTOVA Alexandra ${ }^{1}$, GLUBOKOVA Nadezda ${ }^{2}$, AGAPOVA Anna ${ }^{3}$, ALYSHEV \\ Ivan $^{4}$, LARKOVA Elizaveta ${ }^{5}$, LOMAKINA Daria $^{6}$ \\ ${ }^{I}$ Department of History and Socio-Cultural Service, Southwestern State University, Kursk (RUSSIAN FEDERATION) \\ ${ }^{2}$ Department of Accounting and Taxation, Plekhanov Russian University of Economics, Moscow (RUSSIAN FEDERATION) \\ ${ }^{3}$ Department of Accounting and Taxation, Plekhanov Russian University of Economics, Moscow(RUSSIAN FEDERATION) \\ ${ }^{4}$ International School of Business and World Economy, Plekhanov Russian University of Economics, Moscow (RUSSIAN \\ FEDERATION) \\ ${ }^{5}$ International School of Business and World Economy, Plekhanov Russian University of Economics, Moscow (RUSSIAN \\ FEDERATION) \\ ${ }^{6}$ International School of Business and World Economy, Plekhanov Russian University of Economics, Moscow (RUSSIAN \\ FEDERATION) \\ E-mail: glubokova@mail.ru
}

\begin{abstract}
International taxation, as follows from the theory, is a study of the tax burden on individuals or legal entities in accordance with the tax laws of different countries or international law. Russia, the United States and the EU are global jurisdictions with the most complete tax legislation concerning transfer pricing. In this regard, it is very useful to consider the experience of countries with different principles of taxation of international transactions, which will undoubtedly contribute to improving tax control over international transactions. As a rule, when performing cross-border transactions, the state implements additional control measures, in particular, tax control over transfer pricing. Foreign trade transactions, if the subject of such transactions are goods that are part of one or more of the following commodity groups (oil and goods produced from oil; black metals; non-ferrous metals; mineral fertilizers; precious metals and precious stones) in Russia belong to the category of controlled ones, which necessitates the use of transfer pricing methods. The audit is carried out in relation to the main taxes, namely, VAT, income tax, mineral extraction tax and personal income tax (in relation to individual entrepreneurs), as well as tax on additional income from the extraction of hydrocarbons. The article examines various tools and methods of control over international transactions carried out by both residents and non-residents. The authors consider the experience of countries with different principles of taxation of international transactions, which will contribute to improving and increasing the efficiency of tax control over international transactions, the correctness of calculation and completeness of payment of taxes when applying transfer pricing.
\end{abstract}

Keywords: cultural approach, linguistics taxpayers, income tax, transfer pricing, international transactions, cross-border trade, tax code, tax rates, tax policy

JEL: F39

DOI: 10.5937/intrev2103186B

UDC: 336.225.673

339.5(1-192)

COBISS.SR-ID 55194889 


\section{INTRODUCTION}

This paper examines Russia, USA and EU for their law basis for transfer pricing methodologies and overall international tax practice regarding international trade. Constantly increasing international trade and mobility of goods and services as well as capital and people is contributing to the increasing importance of cross-border payments. International trade has significantly increased over the last 10-20 years. Internationalization of global production makes supply chains as global as never before. For instance, the global value of trade exports has increased by more than $20 \%$ and of exports of commercial services by 46\% between 2008 and 2018 (based on World trade statistical review 2018). Cross-border activity contributes to the growth of P2B cross-border payments (P2B - Person-to-Business) and is assessed to grow evenly and higher in the next years. International travel and people migration continue to increase as well [1][2]. This creates the growing need for cross-border payments.

International tourist turnover worldwide grew more than 50\% during the past 10-year period which leads to most migrants sending earned money back home in order to support their families [3]. Thus, annual money in- and outflows grew over 50\% during the past 10 years [4][5][6]. Such trends in the real economy prove the importance of cross-border payments. However, comprehensive and comparable data on crossborder payments cannot be available ad-hoc due to lack of commonly introduced search definitions and coordination of big data collection efforts and methodology. Mostly cross-border payments are transferred through the specified banking network being either single or a bunch of transactions.

Thus, due to absence of comprehensive data on cross-border payments, it is crucial for governments to implement security measures. Therefore, states ensure stability through tax codes and other law amendments to the international liabilities operations and trade [7]. Every country has its own taxation principles for international transactions besides international law as the main regulator for such processes. This research considers Russia, EU and the USA as subjects (Russia is considered to be a developing country whereas EU and the USA are developed ones with laws being slightly ahead in practical usage) with object of analysis being their policies and laws on international transactions.

\section{MATERIALS AND METHODS.}

\section{METHODS USED IN RUSSIA}

Biggest part of currency restrictions in Russian Federation were removed in 2007 by the amendments to Federal Law No. 173-FZ "On Currency Regulation and Currency Control" dated 10 December 2003. Since then, the majority of currency transactions may be made without any limitations. Still, Law on Currency Regulation and Currency Control has some restrictions to be considered in currency transactions:

- transactions between residents and non-residents (import/export);

- import and export of cash foreign currency.

\section{TRANSACTIONS OF FOREIGN CURRENCY AMONG RESIDENTS}

Residents of the Russian Federation are (but not limited to):

- Russian Federation citizens;

- foreign citizens and stateless people lastingly living in the Russian Federation based on a residence permit;

- legal entities listed under the Russian authority as well as offices and representative offices of Russian legal entities established out of the Federation of Russia.

Although contracts in Russian Federation can be inferred regarding foreign currencies, original payments need to be made in rubles. In light of alterations made to the law of Currency Control in 2013, particular foreign currency transfers and rubles can be considered to be currency operations. Particular Russian Federation residents are banned from opening accounts overseas or commencing transactions with exotic financial instruments. This is applicable to those of the federal, state or municipal positions. Generally, these people are called «politically exposed persons» or «PEPs». 


\section{THE TRANSACTIONS OF FOREIGN CURRENCY AMONG NON-RESIDENTS}

Non-residents of the Russian Federation are:

- foreign nationals that are not qualified as residents [8];

- legal entities listed under the foreign jurisdiction legislation and settled out of the Federation of Russia as well as representative offices of corporations under the foreign jurisdiction legislation placed in Russia[9];

- official representatives of foreign countries and legal entities provided they have international company status [10].

Payments in cash shouldn't be more than RUB 100,000 (or permissible in the equivalent in a foreign currency). Settlements in RUB for securities sale between non-residents are permitted as well, although it can be subject to Russian regulations.

\section{THE TRANSACTIONS OF FOREIGN CURRENCY AMONG RESIDENTS AND NON- RESIDENTS}

Instruction No. 181-I of the Central Bank of the Russian Federation dated March 1, 2018 considers abolishing the obligation to transaction passport opening that will document foreign currency transactions among a citizen and a non-citizen. To substitute this rule, Russian authorized banks are nowadays needed to extract and store information upon foreign trade transactions of both residents and non-residents (for the first ones in any currency, for the second ones in rubles). This is implemented by the tool of register contracts on such transactions. In other words, contracts need to be registered if their value surpasses:

- 3 mln. RUB for import contracts or facility agreements;

- 6 mln RUB for export contracts [11].

To file an export contract, the exporter has to submit the following documents to the authorized bank:

information about the export agreement which should be adequate for its registration: currency; type; number; the contract date; the contract value; date of contractual obligations performance; details of the non-resident counterparty [12][13];

- export contract on its own.

- To register, a citizen (an importer) needs to give the corresponding import contract to the Russian authorized bank [14].

\section{PROCEEDS REPATRIATION}

There is a law that citizens have to repatriate domestic and foreign currency earned from global activities to their bank accounts maintained within authorized banks of the Russian Federation.

Besides that, the amendments to the Law on Currency Regulation and Currency Control introduced and utilized over August 2019 terminated the repatriation necessity for the contracts among citizens and non-citizens about these contracts being denominated in rubles. Thus, now the ruble proceeds due to the citizen under those agreements credited to the resident's account at a foreign bank (not in the country of residence). The repatriation requirement abolition became effective starting from January 1, 2020. The exceptions regard supply contracts concerning specific categories of goods listed in these amendments. This means that to these categories, the repatriation requirement abolition would be implemented gradually.

In May 2014, the Government of the Russian Federation decided to introduce a legal requirement that Russian companies in rubles must receive a portion of export proceeds. In this relation, the Law on Currency Regulation and Currency Control was amended in order to provide the Government with the right to determine:

- the proportion of these export proceeds which need to be obtained by the citizens in local currency (rubles);

- Goods and services list to which these requirements apply;

- Countries and residents list. A Russian resident (out of these lists) determines whether he or she is required to commence an export operation with such compulsory ruble part payment. 


\section{FOREIGN CURRENCY'S IMPORT AND EXPORT IN CASH}

Citizens and non-citizenscan can export and import foreign currency in cash. However, these operations are subject to the following rules (Table 1).

Table 1. Import and export of cash restrictions, USD

\begin{tabular}{|l|l|}
\hline Criterion & Restrictions \\
\hline Up to USD 10,000.00 inclusive & without limitation \\
\hline Over USD 10,000.00 & Subject to a written customs declaration \\
\hline
\end{tabular} Drafted by authors basing on the Federal No. 173-FZ Law "On Currency Regulation and Currency Control"

\section{AMENDMENTS TO THE TAX CODE OF THE RUSSIAN FEDERATION: RELAXING OF TRANSFER PRICING CONTROLS}

On January 1, 2019 the Tax Code of the Russian Federation amendments upon direct and indirect alterations to the rules of transfer pricing in the Russian Federation became effective. These amendments concern:

- The cross-border transactions pricing- it is directed to control procedures as long as the income's total amount for the specified period (generally, 1 year) exceeds RUB $60 \mathrm{mln}$;

- control of the domestic transactions pricing between the related parties of the contract - it is applied alone if both subsequent requirements are fulfilled:

- parties use varied corporate income tax rates or various tax regimes and also:

- determine the mineral extraction tax as a percentage of their tax base;

- are excluded from the income tax payment;

- are excluded from VAT or practice a tax deduction investment.

The total income amount among the associated parties for the analyzed year surpasses RUB $1 \mathrm{bln}$.

In case tax authorities make transfer pricing adjustments concerning one party of the contract, the other party is entitled to the same level of adjustments. The rules for such adjustments are written down in Article 105.18 of the Tax Code of the Russian Federation. If any additional taxes are estimated for one party from the audit findings and elaborations, the other party can adjust the prices to those that tax authorities used for adjusting the other party's tax base and tax liabilities. This means that the other party to the contract is entitled to a symmetrical reduction of its tax base and tax liabilities. Generally, this is equal to the increase in the first party's tax base and tax liabilities [15][10]. The party is entitled to a symmetrical adjustment starting from the date they receive a notification from the tax authorities saying about the availability of a symmetrical adjustment. This is legal, provided that the other party complies with the tax authorities' assessment.

\section{POTENTIAL CONSEQUENCES}

These amendments to the Tax Code of the Russian Federation have a great impact on transactions dated after January 1, 2019. Although the prices between the affiliated individuals (parties: entities or individuals) within domestic as well as cross-border transactions are deleted from transfer pricing control, still, official tax authorities have the right control it within a general tax audit using the usual transfer pricing methods.

In the case of a general tax audit, in the transfer pricing techniques application, it is rarely likely to utilize so-called defense mechanisms that may be implemented if the audit is on the basis of Section V.1 of the Tax Code of the Russian Federation.

When it comes to real cases, tax authorities apply transfer pricing methods as body of evidence at the general tax audit and obtain a sheer number of incidents because taxpayers don't produce a proper transfer pricing analysis during their activities.

Still, although transfer pricing documentation is not obligatory at the practice of the general tax audit applying the transfer pricing methods, the appearance of transfer pricing documentation enhances the possibility of a confident result. 
regarding that, the corporations are recommended:

- to elaborate the defensive position, in other words, the justification of the most applicable transfer pricing methods which include benchmark analysis and other calculations of the corresponding indicators [16]

- to estimate the need for transfer pricing analysis and transfer pricing documentation with affiliated companies which allows to assess potential tax risks as well as to strengthen company's position in terms of complicated challenges from the authorities presenting this tax audit [17].

\section{THE TRANSFER PRICING ADJUSTMENT FOUNDATION}

The Russian tax authorities are entitled to adjust transfer pricing concerning:

- corporate profit tax;

- individual income tax;

- mineral extraction tax (if goods are subject to the above tax at a percentage rate);

- VAT (if the counterparty is exempt from Russian VAT or is not a VAT taxpayer in Russia.

This new law introduced the concept of a market price range meaning the effectiveness concept of prices range or profit level indicators. Tax authorities are now able to adjust prices for tax purposes if the price is not within the determined market range of prices (the price applied in a controlled transaction or their profitability). This new law introduced an adjustment mechanism for Russian companies in order to avoid double taxation with respect to domestic transactions. Given the fact that tax authorities adjust the tax base for the ordinary Russian taxpayers the other party of the controlled transaction is entitled to claim a corresponding adjustment to its tax base (a Russian resident). The new law refers to correlative adjustments related to Russian domestic transactions only [18][19][20].

\section{METHODS USED IN THE USA}

General scheme of taxation. The general global transactions pattern in the USA is divided into 2 classes: taxation of US residents and non-US residents. As for corporate taxation, the same principle can be applied (domestic companies and foreign ones). National organizations are subjected to U.S. tax on their income received all around the world - income from all sources, whether received from operations in the USA or abroad. Foreign corporations are considered subject to taxation of the USA on two main sources of interest: investing income from different U.S. sources and income that is actually associated with either trade or business activity on the U.S. market. Investment income includes following sources: interest, dividends, rents and royalties. The mentioned income involves profits on the assets' sale, which generate investment returns. Before we consider the taxation of the international transaction details in the U.S.A, it is important to introduce important key concepts of the American tax law:

- corporate residency: national and international organizations;

- Income Source: Income from a US source and from a foreign source;

- Income type: investing as well as business income; and

- bilateral agreements on income tax [21].

\section{INCOME SOURCE}

According to U.S. Tax Code, the entire income earned by the corporations can be broken down into two groups - U.S. source and foreign source income. As a rule, a gain of the foreign company received from the U.S. source is subjected to U.S. tax. In contrast, the income of foreign sources is excluded. The most conventional types of income are listed below:

1. Interest and dividend income - they are levied depending on the obligator residence.

2. Royalty income from using immaterial property (patents, trademark and ither intellectual property) - it goes to the nation where the intangible asset is either registered or applied for production. 
3. Rental income - it is levied by the country where the property is located and registered.

4. services provision income- it is levied by the place the services are presented.

5. Wholesale goods' sale income - it is levied by the place where the legal succession between buyer and seller arises

6. Manufactured goods' sale income - this kind of income is levied fifty percent by the place where the goods are produced and the other half to where the legal succession between buyer and seller arises.

7. Earnings from the corporate stocks and bonds' sale - the profit received from investment activity is levied by the place where the issuer is registered.

8. Earnings from the real property sale - this profit is levied by the property

's location.

Income types. A taxable income of a foreign company in the USA can be split into two categories: either investment income or income that is associated with company operating activity on the U.S. market (further - "effectively connected income"). As it has already been mentioned in the paper, investment income includes interest, dividends, rents from real estate, royalties from the use of any intangible asset is called FDAP (FDAP stands for "fixed or determinable annual or periodical gains, profits, and income." It considers gains from the sale of any asset that leads to increase of FDAP.

Under the tax code of the USA, the statutory tax rate is $30 \%$, but as a rule, it can be reduced under the application of the most appropriate tax treaties. Effectively connected income considers business income that arises from U.S. activities. First of all, for having effectively connected income, a foreign company needs to own a U.S. business or trade. Such kind of income is taxed in the same way as U.S. corporations.

\section{TAX TREATIES OF BILATERAL INCOME}

The role of bilateral income tax treaties in the taxation of international transactions is hard to underestimate. They are designed for risk elimination that is connected with double taxation issues and designate the power to tax international commerce in the USA. Therefore, it is worth paying attention to U.S. law, as well as to its income tax treaties contents.

- Residency Tie-breaker Rules - The U.S. government regards any corporation established following its regulations as a U.S. resident. As a lot of conflicts may arise in residency determination, income tax treaties help to resolve all these issues.

- Reduction of Withholding Tax on Fixed, Determinable, Annual, or Periodical (FDAP) income FDAP income is subject to a withholding tax at the statuary tax rate $(30 \%)$.

- Limitation of Benefits - practically every U.S. income tax treaty contains obligatory limitations of benefits provisions used to restrict third-country entities/people from obtaining advantageous treaty benefits

- The exchange of information - one of the most important functions of income tax treaties is to strengthen income tax laws on international transactions. Thus, many income tax treaties maintain certain data giving provisions that allow other parties' tax information exchange and coordinate enforcement activities.

Foreign companies' taxation. Income from investment activity. There are many ways for investment activity implementation: buying U.S. companies and federal governmental units' securities as well as investments in non-commercial assets. Investing in shares of American corporations entails dividend income and profits from the sale of shares; and dividends paid by a US corporation are levied at 30 percent withholding tax (or lower according to income tax treaties).

Profits from the corporate stock sale implemented by a foreign company are not levied according to U.S. tax legislation. Still, if more than 50 percent of the corporate is a part of U.S. real property interests, the gain from the sale of this stock is levied according to U.S. tax legislation [22][23].

Investments in shares of unincorporated US companies are treated differently from investments in corporate shares. Unincorporated organizations (partnerships and limited liability companies are taxed as partnerships) are levied on a straight-through basis. This means that the owners of the capital of these organizations are subject to US tax on their distributable share of the company's income. The nature and 
nature of the income is transferred to the owner. Consequently, if the entity has an actually tied income, the owner will have an actually tied income. The owner must file US income tax returns [24].

Income from business activity. A business operation is considered to be conducted in the United States if the business is generating effectively connected income effectively. Technically, it is possible that there is a trade or business in the United States that is not generating effective tied income. However, from a practical point of view, such activities are not subject to US tax code. Therefore, as a trade or business in the United States can be considered as any commercial activity that occurs with sufficient regularity in order to reach the level of a trade or business and that effectively generates associated revenue. Effectively tied income consists of three types of income:

1. Defined FDAP Income and Associated Income - Income from FDAP in the USA and income from any source in the US received from the sale of assets that result in income from FDAP are actual fixed income when either asset use - Pass test or business activity test [25]. The asset use test is considered passed if the assets that generate income or income are intended for use in a trade or business in the United States. A business test is passed if doing business in the United States is a significant contributor to income or profit.

2. A source in the United States that is not an FDAP or FDAP-related income. Any non-FDAP US withholding income or capital gains that result in FDAP income are considered de-facto tied income[26].

3. Certain income from a foreign source. The definition of effectively tied income includes three classes of foreign-source income: (1) income from the use or privilege of using intangible personal property in the United States; (2) dividends, interest, and gains on the sale of securities in connection with active banking or financial activities in the United States; and (3) income from sales of inventories abroad attributable to the taxpayer's U.S. office.

Subsidiaries and affiliates of foreign companies.

US subsidiary corporations. A US subsidiary often has additional US subsidiaries overseas. This is done to separate business operations and limit any risk exposure. Under US tax law, certain US parent companies can file consolidated tax returns. This consolidated tax return contains only approved US companies. Foreign companies are usually excluded. The main benefit of filing a consolidated rate of return is that losses from a subsidiary can be used to offset income from profitable subsidiaries and taxation of profits from transactions between members of the consolidated group is deferred [38].

Transfer pricing. In transactions among associated parties, the taxpayer should weigh the issues of transfer pricing. The rules of US transfer pricing have a significant effect on several transaction sorts. Those comprise the goods' sale, the services' provision, utilizing intangible or tangible property, loans 'interest rates, as well as cost-sharing adjustments. The pricing method is heavily dependant on the transaction type (such as the goods sale, the services provision, and the intangible assets use). There are several methods available for most transactions and it is up to the taxpayer to determine which method is considered "best" based on specific facts and circumstances. Taxpayers can face significant penalties if their tax liabilities are adjusted in accordance with the transfer pricing rules [27][28]. A taxpayer can avoid these penalties if they can determine that they have met the following three requirements.

1. The taxpayer must determine his transfer price according to a method specified in the rules.

2. The taxpayer shall prepare documents showing the determination of this transfer price according to the specified method and the appropriateness of using this method. This documentation must be available at the time you file your tax return and must contain all elements required by US tax law.

3. The taxpayer makes these documents available to the tax service within 30 days of requesting the documents.

Methods used in the EU. General approach. Differing from both Russia and US, each EU member state has its own fiscal system. The EU doesn't have a direct part on setting tax rates or collecting taxes. The amount of taxes paid and how collected taxes are spent is also decided by member state's national government. What is thought to be tax efficient in one point of origin, could not necessarily be true for another country within EU region. Therefore, from a company's perspective it is important to determine its operation "best fit". As of 2020, the European Union houses 27 countries. Each member state has a different statutory tax rate, however the average Corporate Income Tax rate in EU sits at 22.5\% [40]. These 
values range from France having the highest rate of CIT (34.4\%), followed by Portugal (31.5\%) and by Germany (29.8\%), while Hungary (9\%), Ireland (12,5\%) are among the lowest CIT rates [41].

The EU however does use direct taxation to oversee some consumer and business policies to ensure companies from one country don't have an unfair advantage over a company in the other, while maintaining a free flow of capital, services and goods in its single market. As of indirect taxation, EU plays a large part in the trade movement between non-EU states. As for the Bilateral tax treaties for residents and non-residents are far different between member states of EU, both between EU states and other countries. Each country within the EU works to expand its trade between non-EU states, in most cases separately from the European block. As such, each member state poses a different potential difficulty and benefit to entering companies within the EU. It must be stated however, that as an OECD study from 2008 shown, Corporate Income Tax (CIT) is said to be one of the most harmful ways to stifle economic growth. Countries which keep a lower CIT rate are said to grow quicker than those keeping a high CIT. However, the corporate tax base upon which the CIT is applied should also be considered. Despite this, it must be mentioned that average EU CIT rate is considered to be below the global average.

The Financial Transaction Tax. After the consequences faced with during the 2008 economic crisis, EU has made a proposal to impose a tax on financial transactions (FTT) within the financial sector. Although not widely used by countries around the world by having just 40 countries having FTT in operation in 2011, several EU states already had FTT as part of its tax range[39]. This concept was proposed to have a minimum rate to be applied across all EU states for the transactions made within financial sector such as the exchange of bonds and shares in addition to the remaining derivative contracts. Given the nature of EU states having independent fiscal systems, the proposition is not being enforced upon each state.

It is said by the proponents of FTT that it's done in order to mitigate the systemic risks of potential future economic crises, while also create a safety cushion for the potential bailouts in the future economic crises [29][30]. Although is said to not affect the day-to-day customer activities between companies and citizens, out of $27 \mathrm{EU}$ states, only 10 are participating in the proposal to include FTT. This shows that even between the EU member states, there is a slight disinterest to impose such a tax.

Double tax agreements. As more corporations do business abroad, different jurisdictions have to decide and impose rules on how income gained in foreign jurisdictions is taxes. Otherwise, the company will result in facing double taxation. For these cases, EU member states have an extensive array of double tax agreements (DTAs). These agreements eliminate double taxation for corporations or individuals who have their primary income in one country, but temporary work in the other. In addition, it can also include holding back taxes on royalties, dividends and interests held by foreign companies or individuals. It does mean however that by doing so, the country gives up part of its tax revenue from cross-border transactions.

Tools used to limit foreign transactions. Despite having different fiscal jurisdictions, one of the powers which EU has on its member states is to impose limitations to the trade and subsequently transactions which come into and outside of the trading block. Although these limits do exist, the EU works to maintain a balance which is said to keep it competitive in the world. This balance is also complicated to maintain since numerous EU states have until recently fought the consequences of the 2008 economic crisis and have criticized the implementation of such limitations.

The main limiting tool that is used is of trade barriers, which together with tariffs are used to maintain and benefit the member states within the EU single market. These limitations on out-of-block trade are helping to keep the EU members safeguarded by keeping their national production more competitive among the worldwide competitors [31]. The reason however is not simply economic. By EU being an important partner on the economic political arena, it is using the trading barriers for its diplomatic action to ensure that its trading partners respect the rules of international trade. In addition, EU often joins with other like-minded partners to improve its action efficiency.

The trading barriers are also used to aid in dispute resolution. Through the regular work of WTO and its committees, EU ensures the correct ruling application of WTO. Examples of such actions include the Ukraine proceedings (export ban on timber), settlement of WTO dispute proceedings with Indonesia (export restrictions on raw materials), Southern African Customs Union (restriction on poultry) shows how the EU commission resorts to the resolution of bilateral dispute settlement, while keeping in mind their arrangements of free trade, neither to the multilateral controversy resolution. In addition, EU has recently 
given a formal proposal to fortify the regulation implementation, which will allow to take additional countermeasures to keep international multilateral and bilateral dispute settlement functioning though EU commission proposal COM (2019) 623, 12.12.2019 21. As such, the EU commission can also request the exporters to use the procedure of Trade Barrier Regulation (TBR).

Another tool used by the EU are the Free Trade Agreements (FTAs). This form of creating deals on behalf of its member states helps EU negotiate with other countries and trading blocks. The member states of have granted the EU exclusive competence to produce trade agreements. The members can however interfere at every step of the agreement implementation. FTA mechanisms work to ensure that market priorities are well managed. The EU has ensured that the businesses, especially SMEs take advantage of these commitments. EU commission uses tools to remove barriers, enforce intellectual property rights (IPR), improve protection and impose measures of defence if necessary. As such, EU poses a large range of indirect tax measures to control the movement of trade and transactions from foreign jurisdictions.

\section{ANALYSIS OF IMPORT AND EXPORT TRADE BARRIERS.}

Focusing on the most recent number of trading barriers imposed, in 2019 the largest EU trade partners affected by the measures imposed have included: China, Russia, South Korea, Australia and the countries within Middle East and Mediterranean region (Saudi Arabia, UAE, Turkey, Lebanon, Egypt and Tunisia). These countries correspond to $98 \%$ of trading affected by the measures imposed in 2019. China, by being the country with the most trade barriers with the EU (38 different barriers) has a long history of imposing barriers of its own. Since 2000, China has imposed an import bn on EU cattle, which has been in effect ever since and in the past year has slowly been lifted by allowing certain imports from a number of countries.

The main contention of new trade restrictions has been of high-tech industries, the impact of which goes down across numerous sectors. It is estimated that a 15bn Eur worth of trade is affected given this barrier imposed by China. A Draft proposed by the EU has given measures for China to work in line within the Cybersecurity Law (CSL). In addition, a growing concern has arisen as 5G networks are being provided by China. From the information gathered by European Commission, the tendering results outcomes favour overwhelmingly Chinese providers despite the competitive position of EU providers. Given the fact that China maintains a state-led model without a fair level in economic relations, it is a systemic competitor to EU. As such, it is unlikely that the trade barriers will be lifted.

The Middle Eastern and Mediterranean region has always been seen as important for EU given its historic and geographical ties. A harmonious trade, in many cases with SMEs is important. Unfortunately, the states in this region have given an important rise in protectionism, which as a result caused trade barriers to be risen with the EU. Algeria by imposing bans, custom surcharges and quota on manufacturing goods arriving from EU has caused tensions between states. Lebanon, had seen new trade barriers imposed of $3 \%$ temporary duty tax on all imports, given the measure imposed by Lebanon on imported oil/petroleum products from the EU.

Turkey by being the $5^{\text {th }}$ largest trading partner, has seen a steady growth in trade since 1996 TurkeyEU Customs Union agreement. The agreement introduced free movement of some agricultural and all industrial goods. However, problems have started in the past years. Turkey has stopped complying with the Customs union by imposing additional duties and export restriction on industrial raw materials from the EU among others. Therefore, EU has imposed a WTO case on Turkey this past year.

Australia has trading barriers for its fuel, which is one of the worst in OECD by ranking $70^{\text {th }}$ worldwide. By having 15 times sulphur content from the EU standard it is incompatible with the Euro 6 regulations. As such Australia has to address the fuel quality for the trade barriers to be lifted. South Korean products imported into EU have seen a lack of tests performed, which has resulted in certain products being import restricted, such as water management systems for ships and child garments until this resolution will be pursued. UAE has seen an important relief of trade barriers as after EU's outreach Emirate's authorities have removed repeated testing and audition of certain consumer product groups, greatly reducing the administrative and cost burden. 


\section{DISCUSSION}

Since 1997 the economic and political relationship of Russia and EU was framed though the bilateral Partnership Cooperation Agreement (PCA). Since then, the bilateral trade between members has grown and reached its peak in 2012. Since the events in 2014, the political relations and trade with Russia have been limited and the dialogue focused just through the WTO. By being the second most restrictive trade partner (34 barriers) after China, the market access for EU has been generally negative. Due to the sanctions imposed by the EU in the mid-2010 and Russia's countersanctions, the trade between these two bodies has been limited. Through additional embargos and import duties expanded in 2017, EU has continued to pursue its import substitution policy within different industries [32][33]. In recent developments, Russia has placed higher import duties on foreign wines and quotas on the export of birch logs. As such, these recent trade barriers although imposed, are expecting to see a quick removal.

Despite Russia's recent ascension to the WTO voicing the benefit of sustained liberalisation, Russia has continued to put measures to favour its domestic products and has placed an aim to increase Russian good share for both state-owned enterprises and governmental bodies [34][35]. Time will show Russia's measures and whether they are in-line with the commitments it set in the WTO [36].

At the same time the EU Commission continues to pursue EU interests to address numerous trading aggravations through technical bilateral contracts through the past years, which are of high concern. Overall, Russia-EU trade relations are seen as problematic, both for trade with companies and Russian individuals in the EU. The majority of the trade barriers imposed are considered political actions from the part of global policy and until the tensions concerning Russia-Ukraine subside, the trade barriers are unlikely to change with the EU [37].

European Union as both fiscal and trading body is seeing a lot of competition across the world. Through the ascension of EEC, ASEAN and NAFTA it should keep looking into ways of maintaining a competitive edge, all while keeping to its free trade vision and diplomatic action. So far it has succeeded in doing so, however a strategy in both direct and indirect fiscal policies may have to be researched in order to have a more direct decision-making opportunities to keep EU moving forwards as a single unit state.

\section{CONCLUSION}

In conclusion, it can be said that the methods used by different jurisdictions vary a lot, still there are certain trends for their unification to some extend in the foreseeable future. Thus, every country has its own taxation principles for international transactions besides international law as the main regulator for such processes. This report considered Russia, the EU and the USA as subjects (Russia is considered to be a developing country whereas EU and the USA are developed ones with laws being slightly ahead in practical usage), with the object of analysis being their policies and laws on international transactions. A very gradual shift can be noted in the tax legislation of the Russian Federation concerning the control of international transactions performed both by the residents and non-residents. Not only are Russian companies strictly controlled but foreign affiliates are under close supervision of the authority as well.

As for the USA, it is worth mentioning that Foreign corporations with the unites states' business transactions encounter multiple taxation layers. Those constitute sales, income, and excise taxes levied by every state, government, federal, and local level. European Union poses a lot of trade barriers to both individuals and companies trying to trade with European Union. On taxation level it is unlikely that European Union will ease down on both number of tax-tariffs and barriers administered on each of the regions, given that the average working wage is seeing an increase, while other less developed countries have a benefit of lower wages, making their products more competitive at large. 


\section{REFERENCES}

[1] Zhou, C., Xie, J. \& Wang, Q. (2016). Failure to Complete Cross-Border M\&As: "To" vs. "From" Emerging Markets. Journal of International Business Studies. Vol. 47, pp. 1077-1105

[2] Wang, F., Wang, X. (2016). Influencing factors and implementation path of government data open and utilization: A Qualitative study based on grounded theory. Journal of Information, Vol. 7, pp. 151-157.

[3] Erel, I., Liao, R. C., Weisbach, M. C. (2012). Determinants of cross-border mergers and acquisitions. The Journal of Finance, Vol. 68, pp. 1045-1082.

[4] Zhang, X., Guo, H. (2016). Cross-border E-commerce and cross-border logistics synergy: Mechanism and path. China Business and Market, Vol. 30(11), pp. 83-92.

[5] Senina, K.V., Kalacheva, O.N. (2020). Study of the impact of the COVID-19 pandemic on rental relations in Russia in order to improve the quality of accounting education. International Conference on Advances in Education (ADVED 2020), pp. 422-428. Turkey: 5-6 October

[6] Pogosyan, V. (2018). Philosophies of Social Behavior Research: Meta-Analytic Review. WISDOM, 11(2): 85-92. DOI: https://doi.org/10.24234/wisdom.v11i2.212

[7] Alworth, J.S. (1998). Taxation and Integrated Financial Markets: The Challenges of Derivatives and Other Financial Innovations. International Tax and Public Finance. Vol. 5, pp. 507-534

[8] Kireyeva, E.F. (2016). Tax regulation in agriculture: current trends, selection of a state support forms. Journal of Tax Reform, 2(3), pp.179-192.

[9] De Mooij, R., Ederveen, S. (2003). Taxation and foreign direct investment: A synthesis of empirical research. International Tax and Public Finance, Vol. 10, pp. 673-696.

[10] Zvereva, O.A., Belyakova, M.Y. (2020). Some aspects of the transformation educational services into a digital environment. 6th International Conference on Advances in Education (ADVED 2020), pp. 156-161. Turkey: 5-6 October.

[11] Akhmadeev, R.G., Kosov, M.E., Bykanova, O.A., Turishcheva, T.B. (2018). Development of venture financing to ensure economic security of a country. Proceedings of the 32nd International Business Information Management Association Conference, IBIMA 2018 - Vision 2020:

Sustainable Economic Development and Application of Innovation Management from Regional expansion to Global Growth, pp. 51-56

[12] Bykanova, O., Avvakumova, I., Akhmadeev, R., Morozova, T., Protasov, M. (2020). Application of tutoring in a project and research activity under basic professional education. International Conference on Advances in Education (ADVED 2020), pp. 170-175. Turkey: 5-6 October 2020

[13] Magsumov, T.A. (2018). Apprenticeship in Secondary Vocational Schools During the Economic Modernization in Late Imperial Russia. Part 1. European Journal of Contemporary Education, 7(4), 918-926. doi: 10.13187/ejced.2018.4.918

[14] Gorlanov S., Medelyaeva Z., Malitskaya V., Chirkova M., Kostyukova E. (2019). Content analysis the term "effectiveness" and the concepts of its quantitative characteristics. Indo American Journal of Pharmaceutical Sciences, Vol. 06 (03), pp. 5293-5298

[15] Acemoglu, D., Johnson, S., Mitton, T. (2009). Determinants of vertical integration: Financial development and contracting costs. Journal of Finance, Vol.63, pp. 1251-1290.

[16] Morozova, T., Lehoux, L. (2019). Practical Aspects of Useful Life Calculation for Fixed Assets in IFRS Reports. Proceedings of the 34th IBIMA 2019, Vision 2025: Education Excellence and Management of Innovations Through Sustainable Economic Competitive Advantage. pp. 47224729. Madrid, SPAIN: NOV 13-14

[17] Buettner, T., Wamser, G. (2009). Tax impact of nonprofit taxes on foreign direct investment: Evidence from German multinationals. International Tax and Public Finance, Vol. 14, pp. 151-164

[18] Becker, J., Fuest, C. (2010). Taxing foreign profits with international mergers and acquisitions. International Economic Review, Vol. 51, pp. 171-186.

[19] Voronova, T. A., Golubtsova, E., V., Maksimov, D. A., Novikova, E. S., Ponomareva, N., V. (2020). The Role of Taxation in the Competitiveness of Russian Education Following Globalization and Digitalization Processes in the World Economy. Turismo: Estudos \&Praticas, Vol. 2, p. 1-7

[20] Dudukalov, E. V., Spabekov, G. O., Kashirskaya, L. V., Sevbitov, A. V., Voronkova, O. Y., \& Vasyutkina, L. V. (2020). Fiscal goals of regulating the activities of the institute of controlled 
foreign companies in the digital economy. Entrepreneurship and Sustainability Issues, 8(2), 972983. doi:10.9770/jesi.2020.8.2(59)

[21] Herger, N., McCorriston, S. (2013). On discrete location choice models. Economics Letters, Vol. 120, pp.288-291.

[22] Katherine, P.K., Thomas, D. G., Joseph, B. (2019). Federal Income Tax. Examples and Explainations. 8th Edition, pp. 43-67

[23] Leong, C., Pan, S. L., Newell, S. (2016). The emergence of self-organizing e-commerce ecosystems in remote villages of China: A tale of digital empowerment for rural development. MIS Quarterly, Vol. 40(2), pp. 475-484.

[24] Diemer, R. (2004). The commission proposals for providing companies with a common consolidated corporate tax base for their activities in the internal market. ERA Forum Vol.5, pp.103-119

[25] Weitzel, U., Berns, S. (2006). Cross-border takeovers, corruption, and related aspects of governance. Journal of International Business Studies. Vol. 37, pp. 786-806

[26] Gan, Y., Qiu, B. (2019). Escape from the USA: Government debt-to-GDP ratio, country tax competitiveness, and US-OECD cross-border M\&As. Journal of International Business Studies. Vol. 50, pp. 1156-1183

[27] Fersko, R., Merabet, H., Cordioli, V. (2004). Cross-border transactions: A roadmap for commercial arrangements between North American and European companies. Journal of Commercial Biotechnology. Vol. 11, pp.72-79.

[28] Korableva, O. N., Razumova, I. A., \& Kalimullina, O. V. (2017). Research of innovation cycles and the peculiarities associated with the innovations life cycle stages. Paper presented at the Proceedings of the 29th International Business Information Management Association Conference Education Excellence and Innovation Management through Vision 2020: From Regional Development Sustainability to Global Economic Growth, pp. 1853-1862.

[29] Mody, A., Sandri, D. (2012). The eurozone crisis and exchange controls. Economic Policy. Vol. 27 (70). pp. 199-230.

[30] Makushkin G.E., Avvakumova, I.V., Logvina, E.V., Kirillova O.V., Nikitina N.N. (2020). The Financial and Economic Strategy Formation at an Enterprise: Its Impact on a Managerial DecisionMaking Process. Proceedings of the 35th International Business Information Management Association Conference, Education Excellence and Innovation Management: A 2025 Vision to Sustain Economic Development during Global Challenges (IBIMA). pp. 2476-2484. Seville, Spain: 1-2 April, 2020

[31] Keuschnigg C., Loterz S., Winner H. (2020). Tax competition and tax coordination in the European Union: A survey: https://www.econstor.eu/bitstream/10419/122170/1/803538588.pdf

[32] Petrova G., Posadneva E., Morozova T. (2019). Leading the Labour Market by the Laws of Supply and Demand. In: Strielkowski W. (eds) Sustainable Leadership for Entrepreneurs and Academics. Springer Proceedings in Business and Economics. Springer, Cham, pp 263-271

[33] Korableva, O., Durand, T., Kalimullina, O., Stepanova, I. (2019). Studying user satisfaction with the MOOC platform interfaces using the example of coursera and open education platforms. Paper presented at the ACM International Conference Proceeding Series, pp.26-30. doi: $10.1145 / 3322134.3322139$

[34] Avvakumova, I.V., Bykanova, O.A., Akhmadeev, R.G. (2020). Improvement of small business owners taxation. 7th International conference on education and social sciences (INTCESS 2020), pp. 532-537. Dubai: JAN 20-22

[35] Zvereva, A., Akhmadeev, R., Morozova, T., Bykanova, O., Avvakumova, I. (2020). Improving access to environmental information for the subjects of tax relations. International Multidisciplinary Scientific GeoConference Surveying Geology and Mining Ecology Management (SGEM 2020), pp. 279-284. Bulgaria: August (5.2)

[36] Kalacheva, O.N. (2020). Comparative characteristic of conditions and results of SME operations in the Russian and European economies. Proceedings of the 35th International Business Information Management Association Conference, Education Excellence and Innovation Management: A 2025 Vision to Sustain Economic Development during Global Challenges (IBIMA). pp. 5534 -5541. Seville, Spain: 1-2 April, 2020 
[37] Ponomareva N., Golubtsova, E., Pakshaeva, A. (2020). The prospects of the Russian personal income tax reform in research proceeding by scientists of foreign universities. 6th International Conference on Advances in Education (ADVED 2020), pp. 162-169. Turkey: 5-6 October

[38] Zvereva, A.O., Golubtsova, E.V., Tsilikova, M.S. (2020). The specifics of the use of tax instruments in the digital trade of the Russian Federation. 7th International conference on education and social sciences (INTCESS 2020), (pp. 44-50). Dubai: JAN 20-22

[39] Bykanova, O.A., Akhmadeev, R.G. (2019). Universal VAT Loyalty Policy for B2B E-Commerce. Proceedings of the 34th IBIMA 2019, Vision 2025: Education Excellence and Management of Innovations Through Sustainable Economic Competitive Advantage (pp. 3046-3051). Madrid, SPAIN: NOV 13-14, 2019

[40] Asen, E. (2019). Corporate Tax Rates \& Rankings in Europe. Tax Foundation [source]: https://taxfoundation.org/corporate-tax-rates-europe-2019/ (reference date: 05. 02. 2021).

[41] Emter, L., Schmitz, M., Tirpák, M. (2019). Cross-border banking in the EU since the crisis: What is driving the great retrenchment?. Review of World Economics. Vol. 155, pp 287-326.

\section{Article history:}

Received 28 October 2021

Accepted 30 November 2021 